\title{
Editorial
}

\section{Global Constitutionalism as agora: Interdisciplinary encounters, cultural recognition and global diversity}

\author{
A N T J W I E N E R, J E F F R E L D U N O F F, \\ J O N A THA N H A ERCROFT, MATTIAS KUMM a n d \\ K R I S Z T A K O V Á C S
}

GlobCon aims to be a place where meaningful discussion of pressing global issues can take place, and where the voices in that debate are drawn from a truly international community. ${ }^{1}$

To facilitate meaningful interdisciplinary discussion, the journal welcomes contributions from a plurality of culturally diverse voices around the globe and invites them to address constitutional matters. The journal was founded to offer a public site where the terms of global constitutionalism are discussed and refined. Through this process, global constitutionalism has become a contemporary reference frame that meaningfully speaks to the 'strange multiplicity' of those affected by global norms. ${ }^{2}$ An inherent challenge of this project remains the commitment to cultural diversity that is part of any normatively defensible global project. At the time and since then, the challenge has been to ensure that global constitutionalism is open to the diverse claims raised by the many, reflecting the range of local constitutional traditions and their shared global meanings-in-use. Accordingly, 'contemporary constitutionalism' must do more than merely projecting 'modern' constitutional traditions, be they liberal, nationalist, or communitarian (Tully 1995), onto literal contemporary claims. This insistence on freeing our scholarly perspectives from the conceptual straightjacket of modern constitutionalism to allow for more cultural diversity follows Jim Tully's observation that

\footnotetext{
$1<$ https://www.cambridge.org/core/journals/global-constitutionalism>

2 J Tully, Strange Multiplicity: Constitutionalism in an Age of Diversity (Cambridge University Press, Cambridge, 1995).
} 
when a demand for constitutional recognition is judged to contradict the norms of constitutionalism by the proponents of these three schools (liberalism, nationalism and communitarianism, AW), what they mean is that it is incompatible with the range of normal usage of the terms of contemporary constitutionalism that is constitutive for their traditions of interpretation. The narrow range of normal usage these three traditions share comprises the 'modern' language of constitutionalism. ${ }^{3}$

To create a site of engagement about the terms of contemporary constitutionalism with a global reach, requires the adoption 'of the broader language of constitutionalism - such as the common law, earlier varieties of whiggism and civic humanism - which provide the means of recognising and accommodating cultural diversity'. ${ }^{4}$

Over the past seven years, this journal has helped establish a novel frame of 'contemporary' global constitutionalism and has steadily built a forum and claimed its place as an interdisciplinary agora for and of the global scholarly community. GlobCon welcomes contributions from the broader language of constitutionalism so as to be able to reflect the range of cultural diversity that marks the global 'normative structure of meaning-in-use' beyond the narrower terms of modern constitutionalism. ${ }^{5}$

\section{Diversity}

To accommodate such broader constitutional language, therefore, we are mindful to facilitate encounters that are interdisciplinary and reflect cultural diversity in the best possible way. To that end, the journal's call for special issue and symposium proposals explicitly emphasises diversity:

The editorial board will prioritize proposals that include the presence and perspectives of individuals from diverse backgrounds. Prospective special issue editors are strongly encouraged to think about how to include a diverse array of scholars in their issue and explain this in their proposal. While we recognize that it is not possible to encompass all forms of diversity in a single project, editors do consider diversity along gender, racial, ethnic, geographic, sexual orientation, and theoretical lines when weighing the merits of a proposal. The editorial board may reject a proposal on the grounds that it lacks diversity, or invite special issue proposers to rework the project to include participants from diverse backgrounds with diverse perspectives. ${ }^{6}$

${ }^{3}$ Ibid 36.

${ }^{4}$ Ibid 37.

${ }^{5} \mathrm{~J}$ Milliken, 'The Study of Discourse in International Relations: A Critique of Research and Methods' (1999) 5(2) European Journal of International Relations 225, 231.

${ }^{6}<$ https://www.cambridge.org/core/journals/global-constitutionalism/call-for-papers>. 
Over the journal's first years, it has become an acknowledged site for scholars with a concern for addressing global issues with a view to enhance justice and fairness, and to identify and further pathways to equal participation in global affairs. We hope that the journal continues to be a leading site where the terms of global constitutionalism are refined, thereby advancing global constitutionalism as a framework of reference for the global issues that matter to people locally, as well as nationally, regionally, and internationally. When founding the journal, we envisaged offering a public site for interdisciplinary encounters as an agora in global view. This goal has been steadily addressed and the interdisciplinary encounters have contributed to charting the map of global constitutionalism. This map will - and should - always remain a work in progress, reflecting a plurality of contestations revealing fault lines and cracks in (global) normative order(s), and which are constitutive for the very terms of global constitutionalism.

To refine that map, we shall keep inviting contestants for their contributions to this process of becoming. From the first seven years' experience, we have noticed that there is room for improvement in attracting as diverse a pool of contributors reflecting as broad a range of intellectual traditions as possible. This realisation has prompted an updated call for papers that asks reviewers explicitly,

to consider whether adequate reference is made to the scholarly literature in the field. Recent studies have highlighted the possible underrepresentation of female and minority scholars in article citations.

The updated call also emphasises the journal's commitment

to ensuring that scholars receive appropriate intellectual acknowledgement through citations, regardless of race, gender, class, professional standing, or other categorical attributes. To that end, we ask referees to pay particular attention to the representativeness of citational practices manifested in all article submissions.

Since the journal's earliest days, change through contestation has been a constant focus. Thus, it was only appropriate that the first editorial introduced the theme of contestation of normative hierarchies within the international legal order. It assessed the Kadi case and its role in affirming the central role of fundamental norms such as human rights in the global normative order while challenging the power of global political institutions. ${ }^{7}$

While only in its eighth year, the journal has witnessed interesting times. The journal was conceived at a time when post-cold war politics suggested

7 A Wiener, AF Lang Jr., J Tully, MP Maduro and M Kumm, 'Editorial: Why a New Journal on Global Constitutionalism' (2012) 1(1) Global Constitutionalism 1. 
that global constitutional reform could support a stronger liberal order. ${ }^{8}$ Subsequent developments suggest that this vision may have been overly optimistic. The upsurge of Daesh and the subsequent 'war on terror', ongoing internal strife in Syria, and novel nationalist politics such as initiated by the British Brexiteers and the Trump followers, as well as the rise of an authoritarian China have resulted in the liberal international order losing some of its global clout. In future issues, the journal will explore what elements of the liberal order are worth protecting and which changes are overdue. Whether and how the manifold contestations of multilateralism, regional orders, or constitutional settlements contribute to this process are questions that we hope future contributors to the journal will address. As we noted in our second editorial,

future authors should realize that they need not be experts on constitutionalism, but should hopefully see global constitutionalism as a theoretical approach that offers a helpful reference frame, or even a 'toolbox' with a view to exploring a range of practices, principles and theories that address constitutionalization in the global realm and its impact on change in the modern international order. ${ }^{9}$

\section{A reference frame}

The thoughtful contributions to this journal to date have demonstrated that global constitutionalism does indeed offer such a reference frame. We would argue that the frame is especially important in times when longlasting normative orders, such as for example the normative order of the Western liberal community, stand contested, or, global violent conflict prevails for prolonged periods of time, such as for example the Syrian war. The rise of recent far-right populist movements in the Philippines, Brazil, the USA, Hungary, and Poland (to name just a few), is symbolic of a rejection of both constitutionalism and globalism. ${ }^{10}$ As we have argued in an earlier editorial, the dual concept of global constitutionalism - as an emerging field and a site of interdisciplinary encounter - has helped create a reference frame that works beyond the modern liberal order of the West. ${ }^{11}$

8 JL Cohen, Globalization and Sovereignty: Rethinking Legality, Legitimacy, and Constitutionalism (Cambridge University Press, Cambridge, 2012).

9 AF Lang Jr., M Kumm, A Wiener, J Tully and MP Maduro, 'Interdisciplinarity: Challenges and Opportunities' (2013) 2(1) Global Constitutionalism 4.

10 See J Havercroft, A Wiener, M Kumm and JL Dunoff, 'Editorial: Donald Trump as Global Constitutional Breaching Experiment' (2018) 7(1) Global Constitutionalism 1-13, for an analysis of how such anti-constitutional movements might unintentionally reinforce constitutionalism.

11 M Kumm, AF Lang Jr., J Tully and A Wiener, 'How Large Is the World of Global Constitutionalism?' (2014) 3(1) Global Constitutionalism 1. 
Indeed, its continuous state of becoming allows the frame to reflect a world of constitutionalism that is much larger than the West. ${ }^{12}$ It is high time to address the Western liberal order's many misleading assumptions and shortcomings. Such a critical turn would begin, for example, by focusing on the constitutive norms of a normative order that represents the diverse norms of 'contemporary constitutionalism'. In addition, postcolonial voices have been calling for an end to patronising practices of global 'othering' and, instead, consider distinct legal practices as equal contributions to the forging a global normative order instead. ${ }^{13}$

To these plural voices, we hope the journal offers an agora for critical and probing interdisciplinary encounters. As the journal enters its eighth year, the question we raised in the first editorial - 'Why a new journal of global constitutionalism?'14 - has run its course. Steadily rising submissions and interdisciplinary cross-references show a growing interest in the subject and document that increasing numbers of scholars from different research traditions find dialogue over global constitutionalism to be fruitful. Despite this successful launch of Global Constitutionalism as the only interdisciplinary journal with a commitment to publish research that speaks equally to an audience in international relations theory, international political theory and international legal theory, the question of what the term global constitutionalism actually stands for, however, remains vital. This was well illustrated by the discussion at a recent roundtable launching the Handbook on Global Constitutionalism at the School of International Studies at the University of St Andrews. ${ }^{15}$ While acknowledging that global constitutionalism matters, the audience kept wondering how to precisely define global constitutionalism. This discussion about the nature, content and scope of global constitutionalism is an important driver for the journal's contributors, readers and editors.

As we noted in the first editorial, global constitutionalism neither defines a concept, nor represents the outcome of an ongoing process of

12 M Kumm, J Havercroft, J Dunoff and A Wiener, 'Editorial: The End of "the West" and the Future of Global Constitutionalism' (2017) 6(1) Global Constitutionalism 1.

13 S Pahuja, 'The Changing Place of the Corporation in International Law' Hersch Lauterpacht Memorial Lecture (Lauterpacht Centre for International Law, Cambridge, 2018) details at <https:/www.lcil.cam.ac.uk/press/events/2018/04/hersch-lauterpacht-memoriallecture-2018-changing-place-corporation $>$.

${ }^{14}$ A Wiener, AF Lang Jr., J Tully, MP Maduro and M Kumm, 'Editorial: Why a New Journal on Global Constitutionalism?' (2012) 1(1) Global Constitutionalism 1.

15 For the event, see: 'The Future of Global Constitutionalism: Launch Handbook on Global Constitutionalism’ A Wiener (Hamburg), A Lang (St. Andrews), N Walker (Edinburgh) and J Harries (St. Andrews) Thursday, 11 October, 5pm, (2018) details at <http://cgc.wp. st-andrews.ac.uk/previous-events/>. 
constitutionalisation in global society. Instead, we presented global constitutionalism as an 'emerging field'. The St Andrews roundtable discussion confirmed that this definition stands also in retrospective, that is, global constitutionalism has come to symbolise an emerging field, rather than a new discipline. It represents a process of becoming rather than a concrete state of affairs. This implies, that global constitutionalism is less tangible as a canon than as a scholarly, conceptual, and political practice. As this editorial will argue, this is the journal's strength and - we hope will remain its key appeal. And the journal has precisely sought to reflect and enable this process by offering its pages as an agora for interdisciplinary debates. As an interdisciplinary team of editors including two international lawyers and two IR theorists, we are happy to see the journal's role in creating a new space within wider academic debates. Moreover, novel research activities and scholarly formats have sought to emphasise and further carve out the journal's offer to be an interdisciplinary site in the social sciences by organising specific events that speak to the agora role including for example, specific agora issues, symposiums and annual workshops.

\section{Interdisciplinarity}

Following the seven earlier editorials that reflected upon meanings of the term global constitutionalism, the development of the field, the purpose of the field in light of political change and the nuances of different approaches to global constitutionalism, ${ }^{16}$ this editorial centres on the journal's facilitative agency. This agency has been strategically developed with a focus on purposeful interdisciplinarity, all the while reflecting the disciplinary progress made in especially if not exclusively, its own editors' experience in the fields of IR theory and international legal theory. By offering an agora for interdisciplinary exchange with the journal as the site of conceptual intervention and debate, Global Constitutionalism provides a space for theoretical advancement that is rare insofar as it allows for original thinking that is otherwise often impeded by leading publications outlets that are bound by a certain disciplinary canon. The facilitative purpose of the format has been demonstrated well by previous and forthcoming agora discussions on the implications of 'Contested Multilateralism' for global constitutionalism; ${ }^{17}$ whether, and if so, how, the outlawry of war changed

\footnotetext{
16 For free access to all previous editorials, please visit <https://www.cambridge.org/core/ journals/global-constitutionalism/annual-editorials>.

17 (2016) 5(3) Global Constitutionalism 295.
} 
international relations and/or the international legal order, ${ }^{18}$ and how the study of 'international practices' advances understandings of global order. ${ }^{19}$

The journal's third editorial asked 'How large is the world of global constitutionalism?' 20 To answer the question, it began by addressing the important interrelating between practices of political contestation, on the one hand, and practices of legal contestation about fundamental norms of justice, on the other. In a global society where plural political authorities ranging from modern to postcolonial states jostle for recognition in the universe of ethical, political, cultural and legal global discourse, both types of practices are intrinsically linked. Given that law is ultimately a social construct, these practices cannot be distinguished meaningfully at all times. To advance change and address global injustice, therefore, stakeholders must be enabled to probe the norms that govern them according to the quod omnes tangit principle (what touches all must be approved by all). This moral right to access sites of contestation enables stakeholders to have a say about the norms that govern them. Addressing this process through the lens of global constitutionalism, allows for 'shifting to the constitutional register', for it 'means contesting or justifying issues in terms of legitimate authority, not merely good or bad policy, justice or injustice, legality or illegality'. ${ }^{21}$

We conclude with a special invitation to submit manuscripts which address on site contestations. Here, we welcome submissions from a wide range of interdisciplinary subfields, ${ }^{22}$ among which we would also especially encourage submissions from researchers who address Global International Relations (Global IR) as a call for political intervention in light of uneven development, plural agency and cultural diversity in global society, on the one hand, and the lacking conceptual tools to address these real-world changes by using conventional theoretical means, on the other. To better address cultural diversity, a group of IR scholars from different theoretical and ideological traditions argued, that in order to advance a fairer approach to diversity and pluralism in global society, we had to move 'beyond critique'. Amitav Acharya the movement's founding author summarises the project's intention and purpose thus: the 'notion of a "Global IR" (...) transcends the divide between the West and the Rest'. To that end, Acharya identifies

18 (2018) 7(3) Global Constitutionalism 295.

19 (2017) 6(2) Global Constitutionalism 167.

${ }^{20}$ M Kumm, AF Lang Jr., J Tully and A Wiener, 'How Large Is the World of Global constitutionalism?’ (2014) 3(1) Global Constitutionalism 1.

21 Compare ibid 1.

22 See the Cambridge core website for the updated call for papers here: <https://www. cambridge.org/core/journals/global-constitutionalism/call-for-papers $>$. 
six main dimensions of Global IR: commitment to pluralistic universalism, grounding in world history, redefining existing IR theories and methods and building new ones from societies hitherto ignored as sources of IR knowledge, integrating the study of regions and regionalisms into the central concerns of IR, avoiding ethnocentrism and exceptionalism irrespective of source and form, and recognizing a broader conception of agency with material and ideational elements that includes resistance, normative action, and local constructions of global order. ${ }^{23}$

The approach complements the pluralist remit of this journal quite well given its detailed intention to enhance IR theory's capacity to account for intersectionalities of political difference, cultural diversity, and a plurality of agency, on the one hand, and to offer a framework from which to advance global change and address global injustice, on the other.

\section{Perspectives from the agora}

This renewed focus on diversity in global constitutionalism is particularly timely in an era where both plurality and constitutionality are under attack. During this moment of crisis, global constitutionalism finds itself in an uneasy position. Right-wing extremists lash out against all forms of 'globalism', seeing transnational institutions such as the United Nations (UN), the European Union (EU), and the European Court of Human Rights (ECtHR) as frustrating the will of the people to advance the will of a disconnected global elite. In a certain sense global constitutionalism has participated both in the transnational movements such as globalisation and international human rights law that have provoked right-wing domestic backlashes against globalism. Yet, global constitutionalism also faces criticism from dissident left voices for being too monocultural, too masculine, and too Western. Consider Aoife and O'Donoghue who argue that,

global constitutionalism needs to not only look to the idealised version of constitutionalism but also its critiques - in particular feminism. Otherwise it risks calcifying elements of both international and domestic law, which have been proven to be harmful to women. ${ }^{24}$

Our call for more diverse contributors is not simply to diversify the defenders of global constitutionalism, but to strengthen the theory and

23 A Acharya, 'Global International Relations (IR) and Regional Worlds: A New Agenda for International Studies' (2014) 58 International Studies Quarterly 647, 647.

24 A O'Donoughe and R Houghton, 'Can Global Constitutionalism Be Feminist?' in S Harris Rimmer and K Ogg (eds), Research Handbook on Feminist Engagement with International Law (Edward Elgar forthcoming). 
practice of global constitutionalism through a process of critique and response. To that end we invite pieces that critique some of the foundational tenets of the liberal order. Consider for instance our recent agora on The Internationalists, ${ }^{25}$ a book that defends the role of international law in the decline of inter-state war. Yet as respondents including Tarak Barkawi ${ }^{26}$ and Anna Geis ${ }^{27}$ point out the assumptions about the decline in interstate violence rest upon very assumptions embedded within the western liberal order. By diversifying the perspectives that are included in our scholarship, we can see how many of our assumptions may be limited or even faulty. Diversifying perspectives means greater attention to issues such as treating popular sovereignty over natural resources as a human right ${ }^{28}$, by looking at non-Western judicial institutions we can discover judicial powers that Western-centric scholarship misses. ${ }^{29}$ By studying diverse perspectives we can also see the commonalities and differences between independence movements ${ }^{30}$ in countries ranging from the UK ${ }^{31}$, to Spain ${ }^{32}$, to the Former Yugoslavia ${ }^{33}$, to Colombia, ${ }^{34}$ to China. ${ }^{35}$ From its founding GlobCon has been a venue for diverse perspectives on international law and international relations. By renewing our commitment to diversity through our new call for papers and special issues we hope to build upon this tradition and

25 O Hathaway and S Shapiro, The Internationalists: How a Radical Plan to Outlaw War Remade the World (Penguin, UK, 2017). See also O Hathaway and S Shapiro, 'Response to Critics' (2018) 7(3) Global Constitutionalism 374.

26 T Barkawi, 'From Law to History: The Politics of War and Empire' (2018) 7(3) Global Constitutionalism 315.

27 A Geis, 'Outlawing War Is Not Enough to Promote International Peace: The Ambivalence of Liberal Interventionism' (2018) 7(3) Global Constitutionalism 342.

28 P Gümplová, 'Popular Sovereignty over Natural Resources: A Critical Reappraisal of Leif Wenar's Blood Oil from the Perspective of International Law and Justice' (2018) 7(2) Global Constitutionalism 173.

29 D Werneck Arguelhes and L Molhano Ribeiro, 'The Court, It Is I'? Individual Judicial Powers in the Brazilian Supreme Court and their Implications for Constitutional Theory' (2018) 7(2) Global Constitutionalism 236.

${ }^{30} \mathrm{~K}$ Fierke, 'Introduction: Independence, Global Entanglement and the Co-production of Sovereignty' (2017) 6(2) Global Constitutionalism 167.

31 S Suteu, 'The Scottish Independence Referendum and the Participatory Turn in UK Constitution-Making: The Move towards a Constitutional Convention' (2017) 6(2) Global Constitutionalism 184.

32 L Moreno, 'Europeanisation and Catalonia’s In(ter)dependence' (2017) 6(2) Global Constitutionalism 218.

33 A Orakhelashvili, 'Kosovo and Intersecting Legal Regimes: An Interdisciplinary Analysis' (2017) 6(2) Global Constitutionalism 237.

34 P Rueda-Saiz, 'Indigenous Autonomy in Colombia: State-Building Processes and Multiculturalism' (2017) 6(2) Global Constitutionalism 265.

35 H Wang, 'Traditional Empire-Modern State Hybridity: Chinese Tianxia and Westphalian Anarchy' (2017) 6(2) Global Constitutionalism 298. 
strengthen our understanding of constitutional practices by including as many different voices from as many different places as is possible within the pages of our journal.

\section{This issue}

The year 2019 starts with a GlobCon special issue on the 'Ideologies of Global Constitutionalism' guest edited by Adam Shinar that aims to provide new theoretical tools and frameworks for reconceptualising global constitutionalism. It seeks to understand what constitutes global constitutionalism by interrogating its underlying ideologies. Marco Goldoni examines global constitutionalism through a materialist lens and provides a neo-Marxist and institutional approach. Other contributions challenge several strands of received wisdom, including the supposed connections between global constitutionalism and neoliberal ideology (Mark Tushnet), as well as conventional dichotomies, such as that between liberal and illiberal constitutional orders (Gila Stopler).

Much of the study of constitutionalism to date has taken Western constitutionalism as the primary point of reference. The 2019 volume of Global Constitutionalism reflects cultural diversity and publishes articles that concentrate on constitutionalism in Asia and Latin-America. David KC Huang and Nigel NT Li examine the classical Chinese conception of 'demo-orientation' and assert that it speaks only to the substantive component of democracy, namely 'government for the people', while neglecting other essential conditions of democracy - procedure and equality. The article by Maartje de Visser and Ngoc Son Bui also focuses on Asia and applies the concept of 'glocalization' to the legal-political realm of constitution making processes in five Asian countries: Bhutan, Nepal, Thailand, East Timor and Sri Lanka. Constitution making and its judicial review are in the focus of the article by Yaniv Roznai, David Landau and Rosalind Dixon. They examine the possibility of 'an unconstitutional constitution', building on a case from Honduras. Given the great interest in contemporary cases of the rise of nationalism and authoritarian populism, the assessment of the new Latin American constitutionalism, discussed by Ana Micaela Alterio, also merits closer attention. Alterio contemplates the ways in which popular constitutionalism, as a response to constitutional populism, can be institutionalised.

The 2019 GlobCon volume features articles focusing on post-colonial and feminist approaches to global constitutionalism. A promising manuscript uses feminist utopias in science fiction to better understand how to dismantle hierarchical structures and how to find approaches to governance not predicated on patriarchy. Another one moves from "mere" critique of 
existing power structures in order to imagine how global conversation might look like. The post-colonial approach foregrounds an in-depth analysis on whether UK's British Overseas Territories are colonies. Thus, the idea of 'persistent colonial constitutionalism' frames the paper of Hakeem Olayinka Yusuf and Tanzil Chowdhury. The authors argue that despite the UK Government's exaltations of self-determination of its Overseas Territories, provisions of colonial governance persist in their constitutions. At a time when the constitutional arrangements of the BOTs are being reconsidered, particularly within the context of Brexit, the article is timely and important.

The 2019 volume deals with further contestations of constitutional concepts and regional orders. Tamas Gyorfi addresses the sceptical voices from the United Kingdom on the legitimacy of the ECtHR but lifts this position out of the context of UK constitutional debates and makes it part of a wider discourse about supranational human rights adjudication. In times when the rule of law is under stress and faces a number of severe challenges, Richard Collins convincingly calls for situating the concept of the rule of law in the context of international legal practice. Mohamed Helal makes the case for a new way of understanding the international order, one that consists of a tripartite constitutive regime. The author argues that his approach is a more accurate description of the international order than one predicated on the 'deep structure' of anarchy. Last but not least, Alex Prichard, Ruth Kinna and Thomas Swann present Occupy as a form of constitutional politics thereby offering a starting point to rethink anarchism in our era of constitutionalism beyond and beneath the state. 